\title{
10. Thailand's Student Loans Fund: An analysis of interest rate subsidies and repayment hardships
}

\author{
Piruna Polsiri, Rangsit Sarachitti and Thitima Sitthipongpanich \\ Dhurakij Pundit University
}

\section{Introduction}

Human capital is important for social and economic development. The most sensible way to enhance the quality of a country's human capital is to promote education. In developing countries, however, access to education, especially at high educational levels, is limited because large numbers of the population are poor. Therefore, the government has to play an important role in establishing a student loans scheme to reduce inequality in education, which will eventually increase the country's economic growth.

From the point of view of the government, as a loan provider, some key issues regarding a student loans scheme are: allocation and distribution, recovery, collection and administration, and repayment conditions. ${ }^{1}$ The government also needs to be concerned about the efficiency of resource allocation to the student loan scheme. From the point of view of borrowers, although they receive the opportunity to access higher education and earn higher incomes, required loan repayments with strict conditions could increase the borrowers' repayment hardship. These issues lead to the trade-off between the government's subsidy and the borrowers' repayment difficulties.

Previous studies have investigated student loan schemes in many countriesfor example, in Australia (Chapman 2006; Chapman and Ryan 2002), Europe and the United States (Johnstone 1986), Africa (Johnstone 2004; Johnstone and Amero 2001), and South-East Asia (Ziderman 2004). ${ }^{2}$ Our goal is to fully analyse both the implicit subsidies related to the Student Loans Fund (SLF) and the repayment hardship of loan recipients in Thailand at an undergraduate level. An important and similarly motivated study by Ziderman (2003) comes to comparable conclusions with respect to both overall implicit subsidies and

1 Loan repayment conditions refer to interest charges and the repayment schedule.

2 Although Thailand's student loans cover upper secondary, vocational and undergraduate education, most student loan schemes around the world cover only higher education (Ziderman 2003). Therefore, in this chapter, our analysis will be based on higher education. 
repayment hardships calculated at the mean of the data. ${ }^{3}$ Most importantly, however, this study is the first to analyse the repayment hardship of SLF loans for graduates with very low incomes.

This chapter first describes the background of the SLF in Thailand, before discussing current issues of the SLF. We then analyse the implicit subsidy and repayment hardships.

\section{Background of the Student Loans Fund}

\section{History of the Student Loans Fund}

The history of student loans in Thailand began in 1996 when the government, led by the Chartthai Party, established the Student Loans Fund (SLF). The idea of student loans, nevertheless, originated in 1995 under the government led by the Democrat Party. ${ }^{4}$ The main objective of the SLF is to enhance access to upper secondary and higher education for students from low-income families. ${ }^{5}$ The ultimate goals are to reduce the inequality of education between the rich and the poor and to develop human resources in the country. This will at least help to achieve economic growth and enhance the competitive capacity of Thailand (Student Loans Fund Act 1998).

To serve its purposes, the SLF provides loans for upper secondary, vocational and undergraduate education to students whose family income does not exceed B150 000 per annum. ${ }^{6}$ It has been allocated in the national budget, on average, B27 billion per annum. As reported by Krung Thai Bank in March 2008, the government had subsidised the SLF for the approximate total amount of B280 billion to about 2.9 million loan recipients from 1996 to 2007.

\section{How the SLF Works}

\section{Loan Budget Allocation and Loan Distribution}

In each fiscal year, the SLF will estimate the total amount of funds needed for loan distribution in that year, and submit a request to the Bureau of the

3 Examples of previous studies are Tangkitvanich and Manasboonphempool (2006) and Ziderman (2003).

4 Under the Thai Rak Thai Party government, the SLF scheme was changed to Thailand's Income Contingent and Allowance Loan (TICAL) scheme in 2006. When the government was ousted by the coup, the TICAL was switched back to the SLF. A detailed discussion of TICAL is provided in Chapman and Luonkaew (2008).

5 The average rate of continuing the upper secondary level, however, declined slightly during the period 1997-99, which was due mostly to the East Asian economic crisis in 1997 (Weesakul 2006).

6 The threshold family income of a loan recipient was originally set at B120 000 in 1996. It was then raised to B300 000 in 1997 and remained in place until 1999, when it was reduced to B150 000, which was the median household income in 2002 (Weesakul 2006; Ziderman 2003). 
Budget in the Ministry of Finance. The annual allocated budget of the SLF will then be divided into: 1) the loan budget for upper secondary and vocational education; and 2) the loan budget for undergraduate education. For our focus, the loan budget for undergraduate education will be allocated directly to each university, through the Commission on Higher Education (formerly the Ministry of University Affairs). The loan budget allocated to a university is based on the number of loan recipients in previous years. At the institutional level, the university's loan committee authorises the distribution of the loan budget to eligible students and oversees the process of loan applications. Within the limitations set by the Commission on Higher Education, a university makes decisions on individual loans distributed to its students.

The SLF loans cover tuition fees and educational-related expenses, as well as living allowances during a study period. For the undergraduate level-which is the focus of our analysis - the loan ceiling for tuition fees and educationalrelated expenses is set differently, depending on the field of study, ranging from B60 000 to B150 000 per annum. The living allowance loan, including accommodation and personal expenses, is limited to B24 000 per annum (Office of Student Loans Fund web site: <www.studentloan.or.th>).

\section{Loan Repayment}

Since the SLF loans are provided to students from low-income families, the conditions for interest charges and principal repayments have been set to lessen the debtors' burden. First, there is a seven-year interest grace period between initial enrolment and the first debt repayment. Second, there is a two-year repayment grace period after a loan recipient graduates or stops borrowing. Following the two-year grace period, the loan recipient is required to repay his or her debt for 15 years. ${ }^{7}$ Third, a flat interest rate of only 1 per cent per annum is charged throughout the repayment period. The annual loan repayment is calculated as the proportion of the total loan, ranging from 1.5 per cent in year one to 13 per cent in year $15 .^{8}$ It seems that the SLF loans have the potential to provide 'consumption smoothing', meaning that the proportion of the loan repayment grows with the borrower's expected earnings. Table 10.1 shows an example of a loan repayment schedule, assuming a loan amount of B200 000.

\footnotetext{
7 A loan recipient may choose to start repaying his or her debt during the two-year grace period. Also, a loan recipient may choose to pay off the debt in less than 15 years.

8 A loan recipient may, however, choose to repay the debt at a higher rate, or more quickly than what is specified in the repayment schedule.
} 
Financing Higher Education and Economic Development in East Asia

Table 10.1 Loan repayment schedule of B200 000

\begin{tabular}{r|r|r|r|r|r}
\hline $\begin{array}{c}\text { Year of } \\
\text { repayment }\end{array}$ & $\begin{array}{c}\text { Loan } \\
\text { repayment } \\
\text { proportion } \\
\text { (\%) }\end{array}$ & $\begin{array}{c}\text { Principal } \\
\text { amount } \\
\text { (baht) }\end{array}$ & $\begin{array}{r}\text { Interest } \\
\text { amount } \\
\text { (baht) }\end{array}$ & $\begin{array}{c}\text { Total } \\
\text { amount } \\
\text { (baht) }\end{array}$ & $\begin{array}{c}\text { Outstanding } \\
\text { principal } \\
\text { (baht) }\end{array}$ \\
\hline 1 & 1.5 & 3000 & - & 3000 & 197000 \\
3 & 2.5 & 5000 & 1970 & 6970 & 192000 \\
4 & 3.0 & 6000 & 1920 & 7920 & 186000 \\
5 & 3.5 & 7000 & 1860 & 8860 & 179000 \\
6 & 4.0 & 8000 & 1790 & 9790 & 171000 \\
7 & 4.5 & 9000 & 1710 & 10710 & 162000 \\
8 & 5.0 & 10000 & 1620 & 11620 & 152000 \\
9 & 6.0 & 12000 & 1520 & 13520 & 140000 \\
10 & 7.0 & 14000 & 1400 & 15400 & 126000 \\
11 & 8.0 & 16000 & 1260 & 17260 & 110000 \\
12 & 9.0 & 18000 & 1100 & 19100 & 92000 \\
13 & 10.0 & 20000 & 920 & 20920 & 72000 \\
14 & 11.0 & 22000 & 720 & 22720 & 50000 \\
15 & 12.0 & 24000 & 500 & 24500 & 26000 \\
\hline Total & 13.0 & 26000 & 260 & 26260 & - \\
\hline
\end{tabular}

Fourth, if a loan recipient is unemployed or encounters a natural disaster, riot or war, he or she may apply for a six-month suspension, but in total not more than two years. If a loan recipient's income falls below the threshold income of B4700 a month, he or she may request not to pay the total amount of the required payment. In this case, the borrower has to pay a minimum of B300 a month or B2400 per annum, and it has to be higher than the interest charged for that repayment period. If a loan recipient fails to repay his or her debt, he or she will face a penalty between 12 per cent and 18 per cent of the instalment principal. Finally, upon a loan recipient's death or disability preventing work, the loan will be automatically forgiven.

\section{Loan Collection}

Krung Thai Bank (KTB), a government-owned bank, is responsible for SLF loan collection. Once the two-year repayment grace period ends, due borrowers are required to contact KTB to arrange the loan repayment by 5 July in that year. The borrowers have two choices for paying back the debt. First, they may pay the total due amount for the particular period. Second, they may apply for an instalment of 12 monthly payments. During 15 years of the loan repayment period, the KTB will inform due borrowers of the amounts to be paid one month before the due date - that is, 5 July. Again, the borrowers have two choices to 
settle the repayment schedule for each particular year. If due borrowers fail to arrange the payment, follow-up by mail, telephone and a home visit will be made depending on the length of the delinquency period.

\section{The Importance of Our Study}

In this study, we focus on the analyses of the implicit subsidy by the government and the repayment hardship of SLF loan recipients. We realise that the implicit subsidy issues have already been discussed in Shen and Ziderman (2008), Tangkitvanich and Manasboonphempool (2006) and Ziderman (2003). There are similarities in many dimensions to the analysis of Ziderman and we consider this to be an important affirmation of policy concerns with respect to the SLF. As is the case with Ziderman (2003), we are able to show the extent to which the implicit subsidy can be traced to different policy components of the loan - that is, interest rates charged, interest grace periods, and repayment grace periods. We find that all components matter and that, roughly, the role of interest rate subsidies is about the same as the other factors combined.

As with Ziderman (2003), we calculate repayment hardships for loan repayments estimated with respect to average incomes; using more sophisticated earnings profiles, we come to quite similar conclusions. More importantly, our study contributes to the policy debate in two unusual respects concerning repayment hardships. First, we are able to calculate repayment burdens for graduates of different ages - and not just at the mean. Second, and most significantly, we are able to estimate the extent of repayment hardships for graduates with very low incomes - those in the bottom decile of the earnings distribution - by both sex and age. Our approach allows us to explore fairly specifically the potential policy trade-off between implicit interest rate subsidies and repayment burdens

\section{Current Issues Concerning the SLF}

\section{Nominal Interest Rate of 1 Per Cent}

The nominal interest rate charged to SLF loans is fixed at 1 per cent until the loans are fully paid. The 1 per cent interest rate assists loan recipients to bear a very low cost for their education because it is much lower than market interest rates. Currently, the term deposit interest rate of the Government Saving Bank is 3 per cent and the interest rate of long-term government bonds is 5 per cent (The Bank of Thailand, as of May 2008: <www.bot.or.th>). This means that the government has to subsidise the SLF at least 2-3 per cent over the 15-year repayment schedule. 
Furthermore, the 1 per cent interest rate charged affects the present value of repayments in the future. Assuming that the average inflation rate is 4 per cent, the government subsidises loan recipients at about 3 per cent. The amount of repayment reduces through time at a real rate of 3 per cent. When the total loans - charged with a 1 per cent interest rate-are fully paid after 21 years (four-year course of study, two-year grace period and 15-year repayment period), the government will receive much less money in real terms.

\section{Grace Period}

The SLF allows loan recipients to start loan repayment two years after their graduation. The two-year grace period for repayment benefits loan recipients, but increases the government subsidy. Moreover, from the loan application date, the borrowers are not obliged to pay interest, or to make a repayment for seven years, meaning that the government has to bear a high cost of lending for the seven-year interest grace period. In addition to this, the SLF allows the borrowers to postpone their repayment for a total period of two years if they are unemployed or face a natural disaster, riot or war.

\section{Administration/Collection Cost}

It is arguable that the administration process under the SLF leads to high expenses because it involves several parties. The SLF hires KTB to be responsible for the loan-approval process and 'normal' loan collection. In the fiscal year 2008, KTB was allocated overall administration costs of about B227 million. ${ }^{9}$ The bank is in charge of loan approval after receiving all relevant documents from borrowers' educational institutions. Through KTB, tuition-fee loans are paid directly to an educational institution, while monthly allowances and expenses are credited to borrowers' KTB accounts. During the loan-collection process, KTB will inform borrowers of the amount of payment, and, if the borrowers fail to repay the loan, KTB will follow-up by mail and phone.

After five years of the repayment schedule, the unpaid loans will be classified as 'delinquent' loans. For the delinquent loans, the Legal Affairs Division of the Office of the Student Loans Fund contracts out law firms to follow-up. From an interview with Professor Dr Boonserm Weesakul, an SLF honorary board member, we discovered that, at the steady state, approximately 34000 cases are sent to law firms every year. The total cost for loan collection paid to law firms is about B521 million, and the SLF planned to spend B14.5 million to publicise the process of loan collection in the fiscal year $2008 .^{10}$

9 B. Weesakul (Personal communication, 10 May 2008) referred to the figures from the SLF's 2008 budget.

10 The figures are from the SLF's 2008 budget. 


\section{Defaults}

The high level of government subsidy to the SLF also stems from default losses. Several students might not meet their loan repayment obligation, meaning that when and if a borrower's income is low for a period, he or she will face difficulty in repaying the loan. Also, some students might still be unemployed after the two-year grace period finishes, or might continue a postgraduate course. In addition, the probability of default loss could be increased by contract breach or the death of loan recipients.

Table 10.2 shows the summary of loan repayments for 1999-2006 due for cohorts of borrowers. Official figures show that, for each due cohort, about 40 per cent of due borrowers commence their repayment in July of the first repayment year, while 60 per cent of due borrowers fail to make any repayment. The non-paying borrowers could include those who are not able to repay and who request a deferral of loan repayment, or those who do not commit to their loan repayment. After the first five years of the repayment schedule, the proportion of payers to due borrowers increases to about 80 per cent. This five-year period is a cutoff point for the Legal Affairs Division of the Office of the Student Loans Fund to handle delinquent loans. The legal procedure to some degree helps force due borrowers to repay loans. Therefore, the first two due cohorts - that is, due cohorts for 1999 and for 2000 - show that about 15 per cent of the due borrowers do not pay after eight years, which should be considered as a steady state. This 15 per cent default loss will be used in implicit subsidy calculations.

Table 10.2 Proportion of payers to total number of due borrowers (per cent)

\begin{tabular}{|c|c|c|c|c|c|c|c|c|c|c|}
\hline \multirow[b]{2}{*}{$\begin{array}{l}\text { Due } \\
\text { cohorts }\end{array}$} & \multirow{2}{*}{$\begin{array}{l}\text { Number } \\
\text { of due } \\
\text { borro- } \\
\text { wers }\end{array}$} & \multicolumn{9}{|c|}{ Repayment year } \\
\hline & & $\begin{array}{l}\text { July } \\
1999\end{array}$ & $\begin{array}{l}\text { July } \\
2000\end{array}$ & $\begin{array}{l}\text { July } \\
2001\end{array}$ & $\begin{array}{l}\text { July } \\
2002\end{array}$ & $\begin{array}{l}\text { July } \\
2003\end{array}$ & $\begin{array}{l}\text { July } \\
2004\end{array}$ & $\begin{array}{l}\text { July } \\
2005\end{array}$ & $\begin{array}{l}\text { July } \\
2006\end{array}$ & $\begin{array}{l}\text { April } \\
2007\end{array}$ \\
\hline 1999 & 18672 & 15.93 & 68.18 & 76.84 & 81.00 & 82.85 & 85.56 & 88.58 & 89.77 & 88.51 \\
\hline 2000 & 66555 & & 38.92 & 74.83 & 76.80 & 79.15 & 79.87 & 82.66 & 87.79 & 87.31 \\
\hline 2001 & 135314 & & & 41.21 & 66.60 & 72.00 & 73.22 & 73.85 & 80.05 & 82.65 \\
\hline 2002 & 207102 & & & & 40.30 & 61.01 & 66.21 & 67.28 & 68.36 & 74.60 \\
\hline 2003 & 226105 & & & & & 39.19 & 58.78 & 61.06 & 62.63 & 62.78 \\
\hline 2004 & 245961 & & & & & & 41.13 & 62.94 & 65.31 & 65.74 \\
\hline 2005 & 281070 & & & & & & & 39.34 & 60.38 & 63.50 \\
\hline 2006 & 275580 & & & & & & & & 45.89 & 62.97 \\
\hline
\end{tabular}

Source: Report on student loan payment and repayment, SLF (1999-2006) by KTB, as of May 2007. 


\section{Implicit Subsidies}

In order to calculate the implicit subsidy, we first assume that an average loan per head of university students, including tuition fees and living expenses, is equivalent to B200 000 for a four-year course.

Table 10.3 shows an average tuition fee (four-year course) and the number of borrowers at each type of university in Thailand. The average tuition fee varies across the type of university. As expected, the average tuition fee per course at a private university is the highest: B180 000. A public university charges approximately B72 000 per course, while the average tuition fee at a Rajamangala university of technology is B48 000 per course. The lowest average tuition fee is B48 000 per course at a Rajabhat university. The proportion of borrowers is 37 per cent at a Rajabhat university, followed by 30 per cent at a private university, 22 per cent at a public university and 11 per cent at a Rajamangala university of technology.

Table 10.3 Average tuition fee per course and number of borrowers, 2003

\begin{tabular}{l|r|r}
\hline \multicolumn{1}{c|}{ Type of university } & $\begin{array}{c}\text { Average tuition } \\
\text { fee (baht) }\end{array}$ & No. of borrowers \\
\hline Private university & 180000 & 100489 \\
Public university & 72000 & 75469 \\
Rajamangala university of technology & 48000 & 39069 \\
Rajabhat university & 36000 & 125546 \\
\hline
\end{tabular}

Source: Office of Student Loans Fund.

Weighted average tuition fee $=$

Average tuition fee per course $\times$ Number of borrowers at each type of university

Total number of borrowers

From these figures, we calculate the weighted average tuition fee per course in 2003, which is about B88 000 per person. To make a simple calculation, we assume that the weighted average tuition fee per course in 2008 is approximately B100 000 per borrower. In addition, university students can borrow monthly expenses, including accommodation and living expenses, from the SLF. According to the borrowing conditions of the SLF, each student may borrow a personal expense loan of B2000 a month (Office of Student Loans Fund 2007). Hence, the total personal-expense loan amount for a four-year course is B96 000 per person. We assume that, together with the tuition-fee loan, an approximate total loan for a four-year university course is B200 000 per person. 
Furthermore, we assume an inflation rate of 4 per cent, which was the average inflation rate from 2004 to 2007. ${ }^{11}$ The inflation rate is used to adjust the amount of loan repayment in each year over the 15-year repayment period to a real term of money. We also assume a discount rate of 3 per cent, which is quoted by a general agreement of Times Preference Experts. We use the discount rate to calculate the present values of total payment, loan amount, and collection costs.

The collection cost is assumed to be 3 per cent of the total payment over the 15year repayment period and it is added to the total loan amount per borrower. Referring to the previous section, the total collection cost is B763 million per annum, including fees paid to KTB and law firms and expenses to promote loan repayment. The approximate collection cost of 3 per cent is the proportion of total collection costs (B763 million) to outstanding loans per annum (B27 billion).

The default loss of 15 per cent is used to adjust the total repayment over the 15-year repayment period. Default loss is assumed to mean that 15 per cent of the borrowers pay nothing over the repayment period, while 85 per cent of the borrowers pay the full amount. These figures are from Table 10.2, which shows that it is likely that 85 per cent of total due borrowers pay back the loan at the steady state (B. Weesakul, Personal communication, 10 May 2008).

The calculation of the implicit subsidy in this study turns out to be similar to Shen and Ziderman's (2008), which is shown in Table 10.4.

$$
\text { Implicit subsidy }=1-\left[\frac{\mathrm{PV} \text { of total payment adjusted by loan loss }}{\mathrm{PV} \text { of total loan amount }+\mathrm{PV} \text { of total collection cost }}\right]
$$

The current SLF is examined under repayment conditions of a 1 per cent nominal interest rate charged to the total loan amount, a two-year grace period of repayment, interest charged three years after graduation, and a repayment schedule of 15 years. In addition to the analysis of the current SLF, we also analyse three comparison SLF schemes, which vary in terms of the number of grace periods of repayment and interest charged. Moreover, we propose to analyse the schemes with the adjustment of the interest rate- 1 per cent versus 7 per cent. The nominal interest rate of 7 per cent is equivalent to a real rate of interest of 3 per cent, given that the inflation rate is 4 per cent. If the government's cost of borrowing is 3 per cent, this interest subsidy will be removed. Table 10.4 shows the results of implicit subsidy calculation of four different schemes with two interest rate regimes.

11 The Bank of Thailand reported inflation rates of 2.7 per cent in 2004, 4.5 per cent in 2005, 4.7 per cent in 2006, and 2.3 per cent in 2007 (<www.bot.or.th>). 
Table 10.4 Implicit subsidies (per cent)

\begin{tabular}{l|l|l}
\hline Nominal interest rate & $1 \%$ & $7 \%$ \\
\hline $\begin{array}{l}\text { Two-year repayment grace period and interest rate charged three } \\
\text { years after graduation }\end{array}$ & 65.68 & 44.62 \\
\hline $\begin{array}{l}\text { No repayment grace period and interest rate charged three years after } \\
\text { graduation }\end{array}$ & 60.57 & 36.44 \\
\hline $\begin{array}{l}\text { Two-year repayment grace period and interest rate charged on } \\
\text { enrolment }\end{array}$ & 50.55 & 20.29 \\
\hline No repayment grace period and interest rate charged on enrolment & 46.60 & 19.92 \\
\hline
\end{tabular}

Table 10.4 shows that the implicit subsidy of the current SLF is 65.68 per cent, which is similar to Shen and Ziderman (2008) and Tangkitvanich and Manasboonphempool (2006). Specifically, Shen and Ziderman (2008) report 28.21 per cent of the loan recovery ratio, incorporating default loss, which is equivalent to 71.79 per cent of the implicit subsidy. Using the same approach as Shen and Ziderman (2008), Tangkitvanich and Manasboonphempool (2006) show that the loan recovery ratio is 33.2 per cent (that is, the implicit subsidy is 66.8 per cent), assuming a discount rate of 4 per cent and the default rate of 10 per cent. The differences in the implicit subsidy calculations derive from different estimation formulas and assumptions of inflation rate, discount rate, default loss, and collection costs.

As with Ziderman (2003), our results indicate that the implicit subsidy is affected significantly by the interest rate charged, the grace period of repayment, and the grace period in which interest is not charged. Interest rate subsidies are an important aspect of the government subsidy and these arise because interest rates charged on debt are typically lower than the government's borrowing cost. If we adjust the nominal interest rate from 1 per cent to 7 per cent-meaning that the real interest rate is 3 per cent (equivalent to the discount rate we use)the implicit subsidy decreases to 45 per cent. This could be roughly summarised as: 1 per cent of the interest rate charged to the loan reduces the implicit subsidy by about 3.5 per cent.

We estimate also the effect of changes in the repayment grace period on the subsidy. Based on other conditions of the current SLF system, the implicit subsidy declines from 65.68 per cent to 60.57 per cent if borrowers are required to make a repayment after graduation (zero repayment grace period). The interest grace period also has an impact on the implicit subsidy. If the interest is imposed on enrolment, the implicit subsidy reduces to 50.55 per cent. Even assuming no grace period of repayment and interest charged on enrolment, the implicit subsidy roughly declines from 65.68 per cent to 46.6 per cent. These results indicate that the impact of the interest rate charged on the implicit subsidy is much stronger than that of the repayment grace period and that of the interest grace period. 
Under the schemes of a 7 per cent interest rate charged on the SLF, the implicit subsidy decreases to 36.44 per cent when there is no grace period of repayment. If we drastically alter the current SLF, assuming a 7 per cent interest rate charged, zero repayment grace period and interest rate charged on enrolment, the implicit subsidy substantially reduces - to 19.92 per cent, ${ }^{12}$ or to less than one-third of the estimate for the current SLF of about 65 per cent. The findings of Table 10.4 suggest that the impact of grace period parameters on the implicit subsidy is greatest at the high interest rate.

We also calculate the implicit subsidy assuming that the default loss is 20 per cent and everything else remains constant. This 20 per cent default loss refers to the proportion of unpaid due borrowers after the five-year cut-off point for the Legal Affairs Division of the Office of the Student Loans Fund to handle delinquent loans. Results available from the authors show that at the interest rate of 1 per cent, the implicit subsidy increases by about 2 per cent, while at the interest rate of 7 per cent, it increases by about 4 per cent, compared with the current SLF with an assumed 15 per cent default loss. As expected, at a higher interest rate charged, the impact of default loss on the implicit subsidy is greater. Adjusting the default loss does not, however, significantly change our analysis of the implicit subsidy.

\section{Repayment Hardships}

\section{Data and Methodology}

To investigate the repayment hardship of loan recipients, we use the age-earnings profile of average Thais with an undergraduate degree provided by Chapman and Lounkaew (2008). ${ }^{13}$ They construct age--earnings profiles of Thai graduates using data from the 2006 Labour Force Survey conducted by the National Statistical Office. The sample is classified into female and male graduates. Their income is measured as wages from their main jobs with a minimum of 20 working hours a week, and the estimated income of average graduates is constructed based on the ordinary least squares (OLS), which is estimated using potential experience (in a quadratic form) and educational background. ${ }^{14}$

\footnotetext{
12 The fact that some subsidies remain can be traced to overall defaults and administration costs built into the analysis.

13 Ziderman (2003) calculates repayment burdens using average earnings only.

14 There is a possible unemployment issue; however, it is probably not very serious because the average unemployment rate of female and male graduates during the 15-year repayment period is only about 8 per cent and 4 per cent, respectively.
} 
Table 10.5 shows the descriptive statistics of the sample's earnings. The number of observations is 6899 and 9871 for male and female graduates, respectively. On average, female graduates earn approximately B172 000 per annum, which is lower than the male graduates' earnings of about B190 000 per annum. The minimum wage of female graduates is B13 200 per annum, while male graduates earn at least B18 200 per annum.

Moreover, to examine how the repayment hardship of loan recipients under the SLF scheme will be different when the loan recipients earn much less than the average, we use the age-earnings profile of graduates whose income is in the bottom 10 per cent - that is, unlucky graduates. To calculate the estimated future income of unlucky graduates, we also use the same regression model as that for average graduates. The descriptive statistics of unlucky graduates in Table 10.5 show that the number of observations for unlucky graduates is 1038 and 668 for female and male graduates, respectively. The minimum earnings of unlucky female graduates is B12 500, but on average they earn B75 994.96. As for unlucky male graduates, their average income is B78 972.62, which is higher than that for females.

Table 10.5 Descriptive statistics of age-earnings profile data

\begin{tabular}{lcccccc}
\hline \multicolumn{1}{c}{ Sub-sample } & $\begin{array}{c}\text { No. of } \\
\text { observations }\end{array}$ & Min. & Max. & Mean & Median & Std dev. \\
\hline Female graduates & 9871 & 13200 & 480003 & 172116.10 & 148800 & 85172.42 \\
\hline Male graduates & 6899 & 18200 & 521440 & 190350.20 & 180000 & 88589.68 \\
\hline $\begin{array}{l}\text { Unlucky female } \\
\text { graduates }\end{array}$ & 1038 & 12500 & 130600 & 75994.96 & 71400 & 25485.52 \\
\hline $\begin{array}{l}\text { Unlucky male } \\
\text { graduates }\end{array}$ & 668 & 6250 & 149400 & 78972.62 & 74600 & 22092.78 \\
\hline
\end{tabular}

The age-earnings profiles over the working life of average female and male graduates and that of unlucky female and male graduates are shown in Figures 10.1 and 10.2, respectively.

To calculate the repayment hardship, there are four sub-samples in our analysis - that is, average female graduates, average male graduates, unlucky female graduates and unlucky male graduates. The repayment hardship is calculated as below:

The total loan repayment of each period is adjusted to a real term, using the inflation rate of 4 per cent and total income, estimated by the regression model, in a real term. 


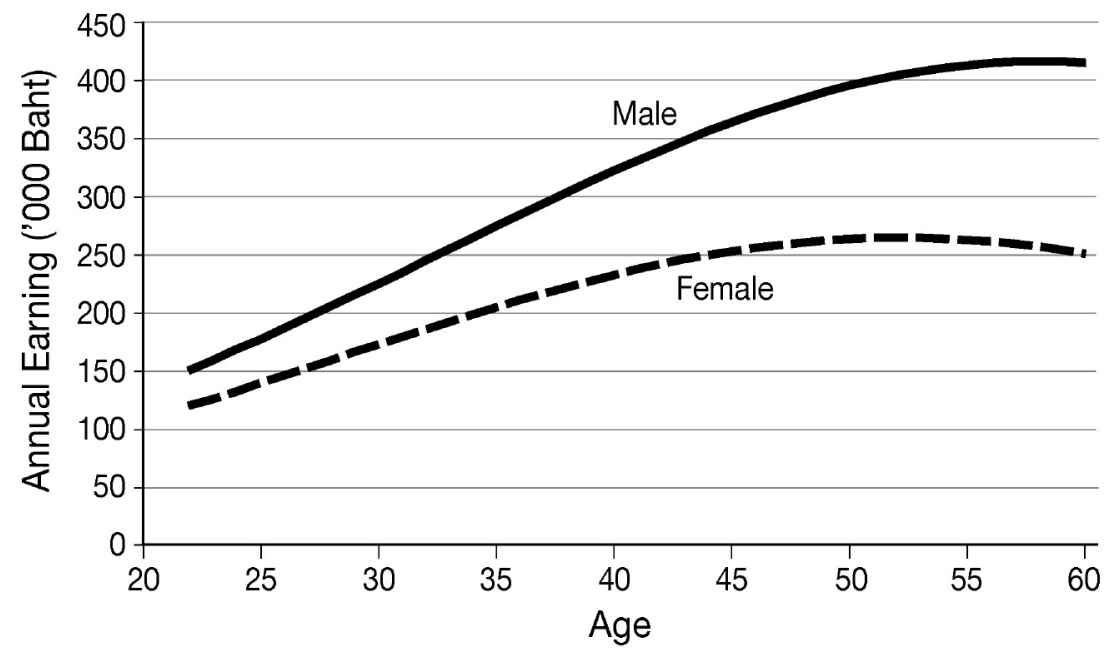

Figure 10.1 Age-earnings profile of average graduates

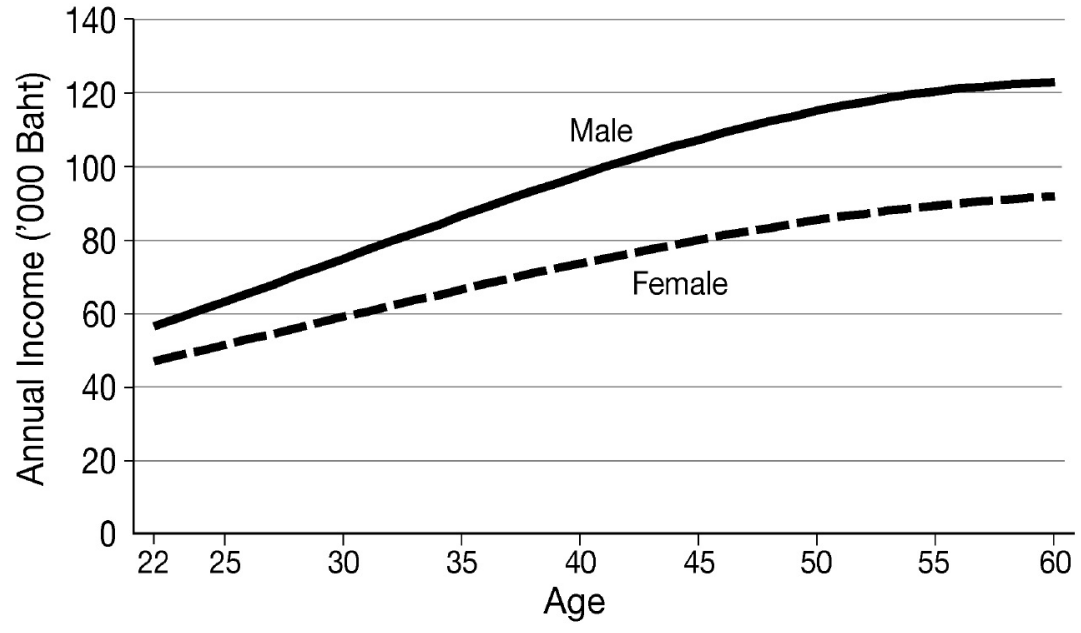

Figure 10.2 Age-earnings profile of unlucky graduates

\section{Analysis}

Consistent with the implicit subsidy analysis, we calculate the average repayment hardship over the 15-year repayment period of average female and male graduates as well as unlucky female and male graduates under the four different SLF schemes. The results are presented in Table 10.6. 
Financing Higher Education and Economic Development in East Asia

Table 10.6 Average repayment hardships (per cent)

\begin{tabular}{|c|c|c|c|c|c|c|c|c|}
\hline \multirow{3}{*}{ Schemes } & \multicolumn{4}{|c|}{ Interest rate $1 \%$} & \multicolumn{4}{|c|}{ Interest rate $7 \%$} \\
\hline & \multicolumn{2}{|c|}{ Average } & \multicolumn{2}{|c|}{ Unlucky } & \multicolumn{2}{|c|}{ Average } & \multicolumn{2}{|c|}{ Unlucky } \\
\hline & Female & Male & Female & Male & Female & Male & Female & Male \\
\hline $2 \operatorname{Rep}, 3 \operatorname{lnt}^{\mathrm{a}}$ & 4.19 & 3.47 & 12.44 & 9.72 & 6.87 & 5.74 & 20.13 & 15.81 \\
\hline 0 Rep, $3 \operatorname{lnt}^{\mathrm{b}}$ & 4.55 & 3.76 & 14.20 & 11.21 & 7.45 & 6.22 & 23.01 & 18.28 \\
\hline $2 \operatorname{Rep}, 0 \operatorname{lnt}^{\mathrm{c}}$ & 4.46 & 3.70 & 13.21 & 10.33 & 9.72 & 8.17 & 28.32 & 22.30 \\
\hline $0 \operatorname{Rep}, 0 \operatorname{lnt}^{\mathrm{d}}$ & 5.12 & 4.33 & 14.79 & 11.69 & 10.22 & 8.78 & 28.95 & 23.06 \\
\hline
\end{tabular}

a 2 Rep, 3 Int = 'Two-year repayment grace period and interest charged three years after graduation'

b 0 Rep, 3 Int $=$ 'No repayment grace period and interest charged three years after graduation'

c 2 Rep, 0 Int = 'Two-year repayment grace period and interest charged on enrolment'

$\mathrm{d} O$ Rep, $O$ Int $=$ 'No repayment grace period and interest charged on enrolment'

As expected, under the current SLF scheme (2 Rep, 3 Int with the interest rate of 1 per cent), the average repayment hardship of the borrowers is the lowest among all schemes. For females and males, we find repayment burdens of 4.2 and 3.5 per cent, respectively. Ziderman (2003) has similar findings - of 3.5 and 2.2 per cent, respectively. The findings of most interest from our exercises relate to repayment hardships for our unlucky graduates.

We find that for unlucky female and male graduates, the average repayment hardship is about 12 and 10 per cent, respectively. Given that Ziderman (2003) argues that repayment burdens of about these levels are acceptable in terms of loan design when calculated at the average, it follows that the current SLF can be considered quite generous.

When we design a comparison SLF by changing the interest rate from 1 per cent to 7 per cent ( 2 Rep, 3 Int with the interest rate of 7 per cent), the average repayment hardship of average graduates increases by roughly 2-3 per cent. The average repayment hardship of unlucky graduates, however, increases about 6-8 per cent. ${ }^{15}$

As previously discussed, the implicit subsidy is very high under the current SLF scheme, but it can be lowered considerably if we remove all forms of subsidisation. The question here is what will happen to the repayment hardship of loan recipients? In other words, how much will the repayment hardship change when: 1) the interest rate increases from 1 per cent to 7 per cent; 2) there is no grace period for loan repayment; and 3) the interest is charged on enrolment? Table 10.6 shows that the average repayment hardship under this radically modified SLF scheme ( $O$ Rep, $O$ Int with the interest rate of 7 per cent) is twice as much for all sub-samples, compared with the current SLF scheme.

15 Again, these findings, based on average incomes, are not very different to those of Ziderman (2003). 
More precisely, the average repayment hardship increases from 4.19 per cent and 3.47 per cent, to 10.22 per cent and 8.78 per cent for average female and male graduates, respectively. As for unlucky female and male graduates, the average repayment hardship increases from 12.44 per cent and 9.72 per cent, to 28.95 per cent and 23.06 per cent, respectively. These findings show that for unlucky graduates, if the government decides to reduce the subsidy for student loans, they might have to pay as much as one-fourth of their income for the loan, on average.

We then compare the repayment hardship over the 15-year repayment period of the current SLF with the radically modified SLF scheme (O Rep, $O$ Int with the interest rate of 7 per cent) for all sub-samples. Figure 10.3 shows that under the current SLF scheme, an average female graduate pays somewhat less than 4 per cent of her income at the beginning of the repayment period, reaching about 5 per cent at the end of the repayment period. Similarly, for an average male borrower, the proportion of loan repayment to income increases from about 3 per cent in the first year to about 4 per cent in the final repayment year.

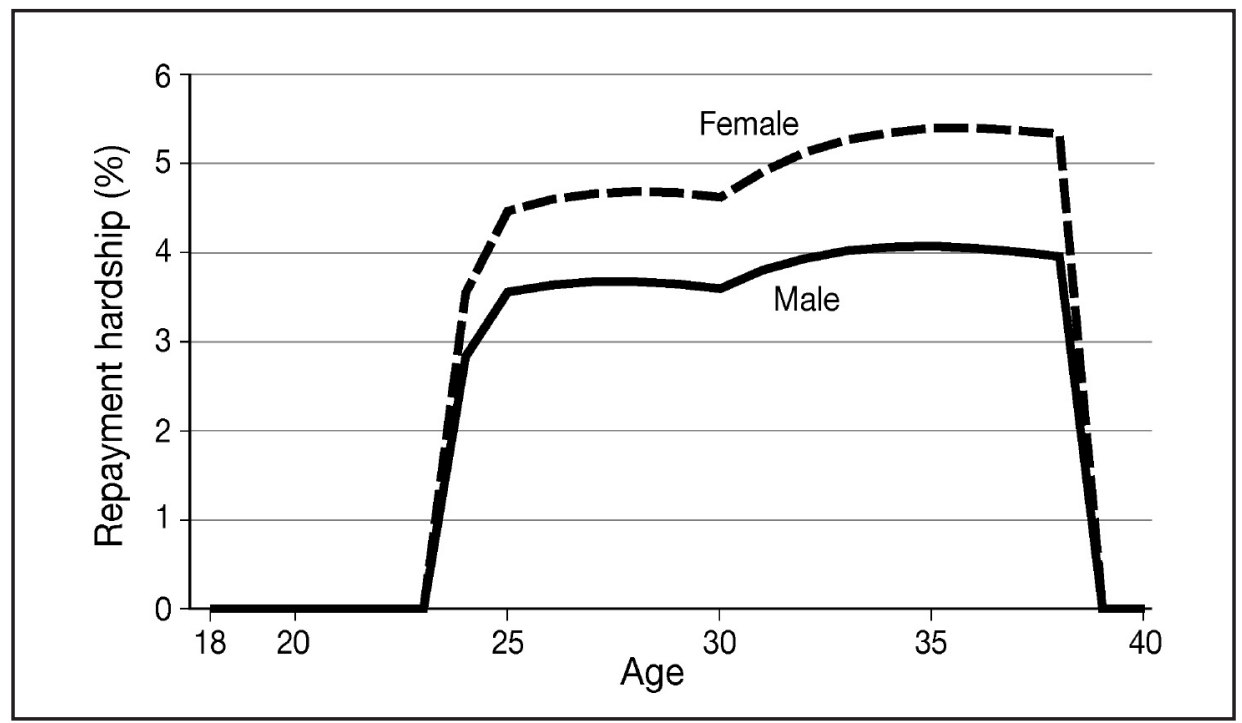

Figure 10.3 Proportion of total payment to total income of average graduates: current SLF 


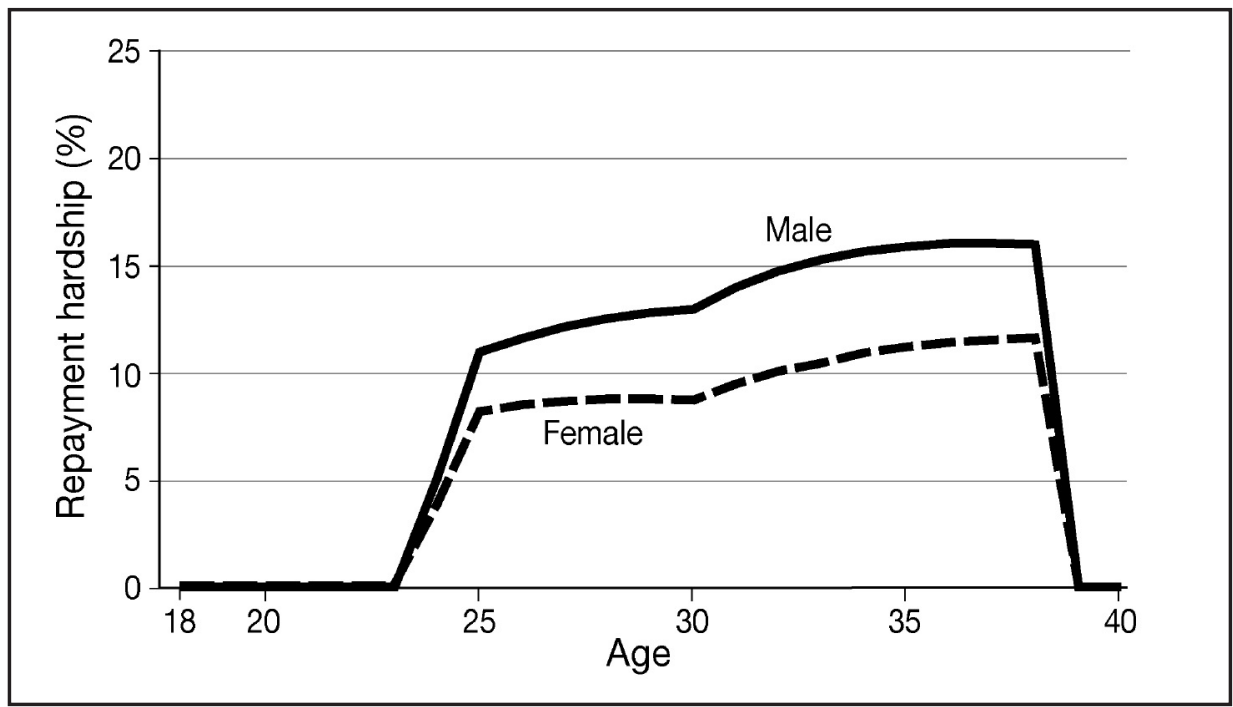

Figure 10.4 Proportion of total payment to total income of unlucky graduates: current SLF

Figure 10.4 shows the repayment hardship of unlucky graduates over the repayment period.

Compared with that of average graduates, the ratio of repayment to income for unlucky graduates is much higher. More precisely, the proportion of loan repayment to income is the lowest at about 8-11 per cent in the first year of repayment, rising to about 12 per cent and 16 per cent for females and males, respectively, in the final repayment years.

The proposed SLF scheme that charges 7 per cent interest on enrolment and requires borrowers to pay immediately after graduation demonstrates a different pattern of repayment hardship than that of the current SLF. This is shown in Figure 10.5 for borrowers (male/female) earning average incomes.

With the subsidies considerably reduced, the data from Figure 10.5 show that an average female borrower repays about 9 per cent of her annual income at the start of the repayment period. This proportion increases consistently, to reach nearly 14 per cent of annual income in the final year of the repayment period. The results are similar for an average male borrower. Nevertheless, the repayment hardship of a male borrower is about $1-3$ per cent lower than that for a female borrower at any given age during the repayment period. 


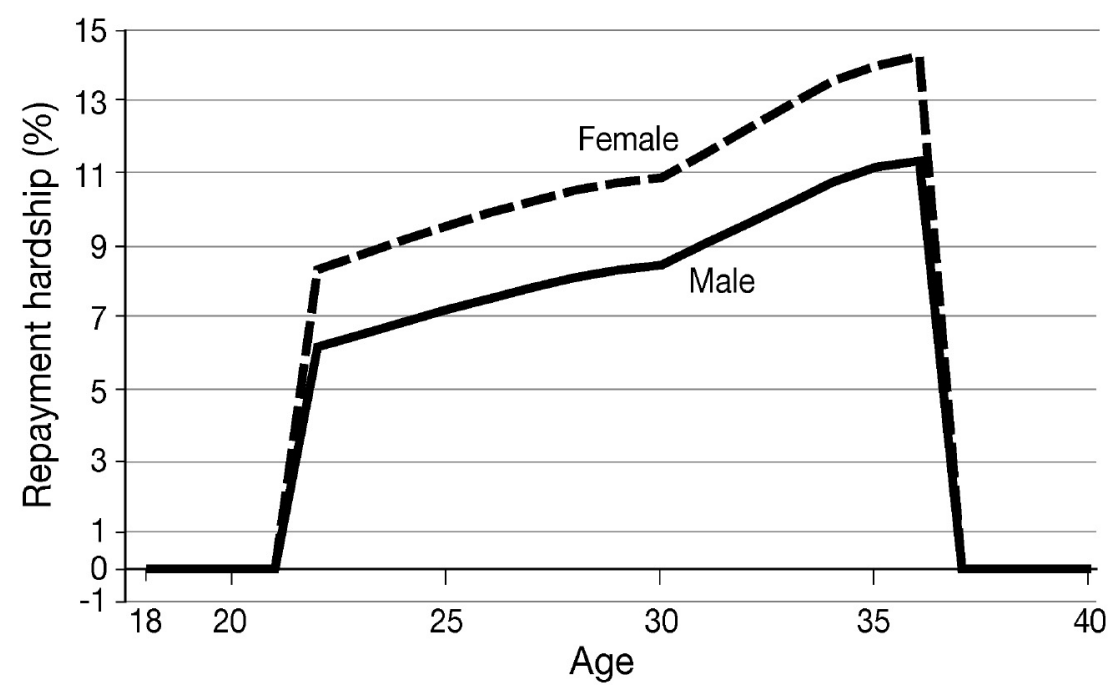

Figure 10.5 Proportion of total payment to total income of average graduates, 7 per cent interest rate, and no repayment and interest grace periods

The repayment hardship of unlucky borrowers is shown in Figure 10.6.

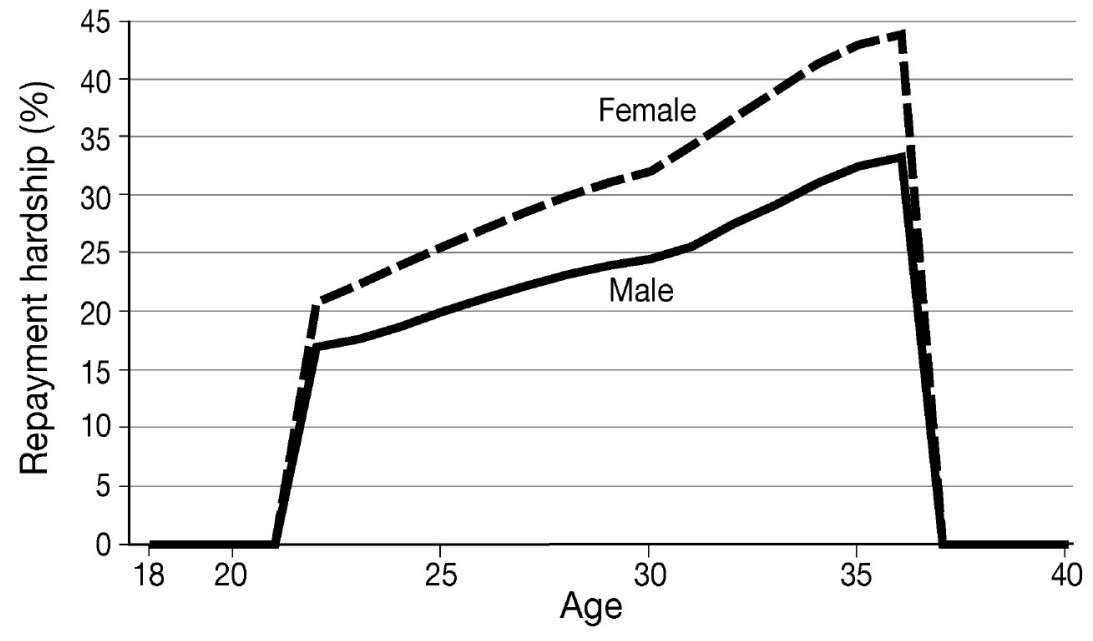

Figure 10.6 Proportion of total payment to total income of unlucky graduates, 7 per cent interest rate, and no repayment and interest grace periods 
The clearest point from Figure 10.6 is that the proportion of repayment to income for unlucky borrowers is substantially greater than that for graduates earning average incomes. Specifically, the proportion peaks about 43 per cent and 32 per cent for unlucky female and male graduates, respectively, in the final year of the repayment period, after being about 20 per cent and 18 per cent, respectively, of annual income in the first repayment period..$^{16}$

The analyses of the implicit subsidy and the repayment hardship suggest that if the government modifies the current SLF by increasing the interest rate to 7 per cent with no grace periods on repayment and interest, a very significant portion of the subsidy is reduced. More precisely, from Table 10.4, the implicit subsidy is reduced by more than two-thirds, while borrowers face greater difficulties in repaying the loan, especially in the first several years. This, then, is the dilemma facing the Thai government with respect to the SLF: the implicit interest rate subsidies are so high as to render the scheme close to a grant, but removing these subsidies results in what could be seen as highly undesirable repayment hardships for the members of some groups. This will undoubtedly lead to higher defaults.

\section{Conclusion}

We have analysed for Thailand the implicit subsidy of the current SLF and the repayment hardships of borrowers. We compare the current SLF with alternative SLF schemes, assuming different grace periods on interest charged and loan repayments. In addition, we assume a 7 per cent nominal interest rate-instead of 1 per cent-for all schemes. This 7 per cent rate is to make the real interest rate of the SLF loan equivalent to the discount rate we have used in the analysis.

Our analysis shows that the implicit subsidy drastically reduces-by approximately 46 percentage points (to less than one-third) - when the nominal interest rate is increased from 1 per cent to 7 per cent and there is no grace period for both the interest charge and the loan repayment. With no changes to grace periods, but using an interest rate of 7 per cent, the implicit subsidy declines by about 21 percentage points. In the case that the interest rate remains 1 per cent, and if the grace periods on interest charges and loan repayments are removed, the implicit subsidy drops by about 20 percentage points. These findings are similar to those reported by Ziderman (2003), implying a strong consensus in this area of analysis with respect to the SLF.

16 We allow direct comparisons of the repayment hardships between average and unlucky graduates under the current SLF and the three proposed SLF schemes in Appendix 10.1. 
We considered also repayment hardship under the current SLF, and, as with Ziderman (2003), we did the calculations using average earnings data. We found the repayment hardships of average female and male graduates to be about 4 per cent and 3 per cent, respectively. But the story becomes much more interesting when we consider repayment burdens for graduates earning in the bottom deciles by age and sex. Specifically, for the SLF, repayment hardships for unlucky female and male graduates are about 12 per cent and 10 per cent, respectively. Given that Ziderman argues that burdens of these levels are acceptable (if estimated at the mean of the data), and we are considering the outcomes for very poor graduates indeed, the SLF is clearly a very generous student loan scheme.

Assuming that the interest rate increases to 7 per cent and the grace periods on interest charged and loan repayments are eliminated, the average repayment hardship of female graduates increases to about 10 per cent, and is about 9 per cent for males (Ziderman 2003 makes very similar findings). A critical finding, however, is that under the same conditions, the average repayment hardship of unlucky female graduates rises to about 29 per cent and for males the figure is 23 per cent. But it is important to note that there are differences between age groups in estimations of repayment hardships, with the figures reaching 43 per cent and 32 per cent for females and males respectively in the last year of repayment. These burdens should be considered excessive and unacceptable in policy terms.

To sum up, the current SLF is very generous in terms of repayment hardship for the borrowers. The scheme appears, however, to be unsatisfactory in terms of the extent of the implicit subsidies. In other words, the repayment hardship of loan recipients is relatively low, while the implicit subsidy is relatively high. Nevertheless, if all forms of subsidy are taken away (that is, the nominal interest rate increases and there are no grace periods on repayment and interest charges) that proportion of graduates earning very low incomes will likely experience great difficulties in repaying the loan.

\section{References}

Chapman, B. 2006, Government Managing Risk: Income contingent loans for social and economic progress, Routledge, London.

Chapman, B. and Lounkaew, K. 2008, Income contingent student loans for Thailand: comparative analysis, Paper presented to Student Loans in South and East Asia Conference, The Australian National University and Dhurakij Pundit University, Bangkok, 15-16 July. 
Chapman, B. and Ryan, C. 2002, 'Income-contingent financing of student charges for higher education: assessing the Australian innovation', The Welsh Journal of Education, vol. 11, no. 1, pp. 64-81.

Johnstone, D. B. 1986, Sharing the Costs of Higher Education: Student financial assistance in the United Kingdom, the Federal Republic of Germany, France, Sweden, and the United States, The College Board, New York.

Johnstone, D. B. 2004, 'Higher educational finance and accessibility and student loan in sub-Saharan Africa', Journal of Higher Education in Africa, vol. 2, no. 2, pp. 11-36.

Johnstone, D. B. and Amero, A. 2001, The applicability for developing countries of income-contingent loans or graduate taxes, with special consideration of an Australian HECS-type income-contingent loan program for Ethiopia, Working Paper, University of Buffalo Center for Comparative and Global Studies in Education, NY.

Office of Student Loans Fund 2007, SLF'S Handbook, (in Thai), Office of Student Loans Fund, Bangkok.

Shen, H. and Ziderman, A. 2008, Student loans repayment and recovery: international comparisons, Working Paper, Department of Economics, Bar Ilan University, Tel Aviv.

Tangkitvanich, S. and Manasboonphempool, A. 2006, Policy evaluation of Student Loans Fund, Working Paper, Thailand Development Research Institute, Bangkok.

Weesakul, B. 2006, Student loans in Thailand: past, present and future, Mimeo., Dhurakij Pundit University, Bangkok.

Ziderman, A. 2003, Student Loans in Thailand: Are they effective, equitable, sustainable?, United Nations Educational, Scientific and Cultural Organisation, Bangkok.

Ziderman, A. 2004, Policy Options for Student Loan Schemes: Lessons for five Asian case studies, International Institute for Educational Planning, United Nations Educational, Scientific and Cultural Organisation, Paris. 


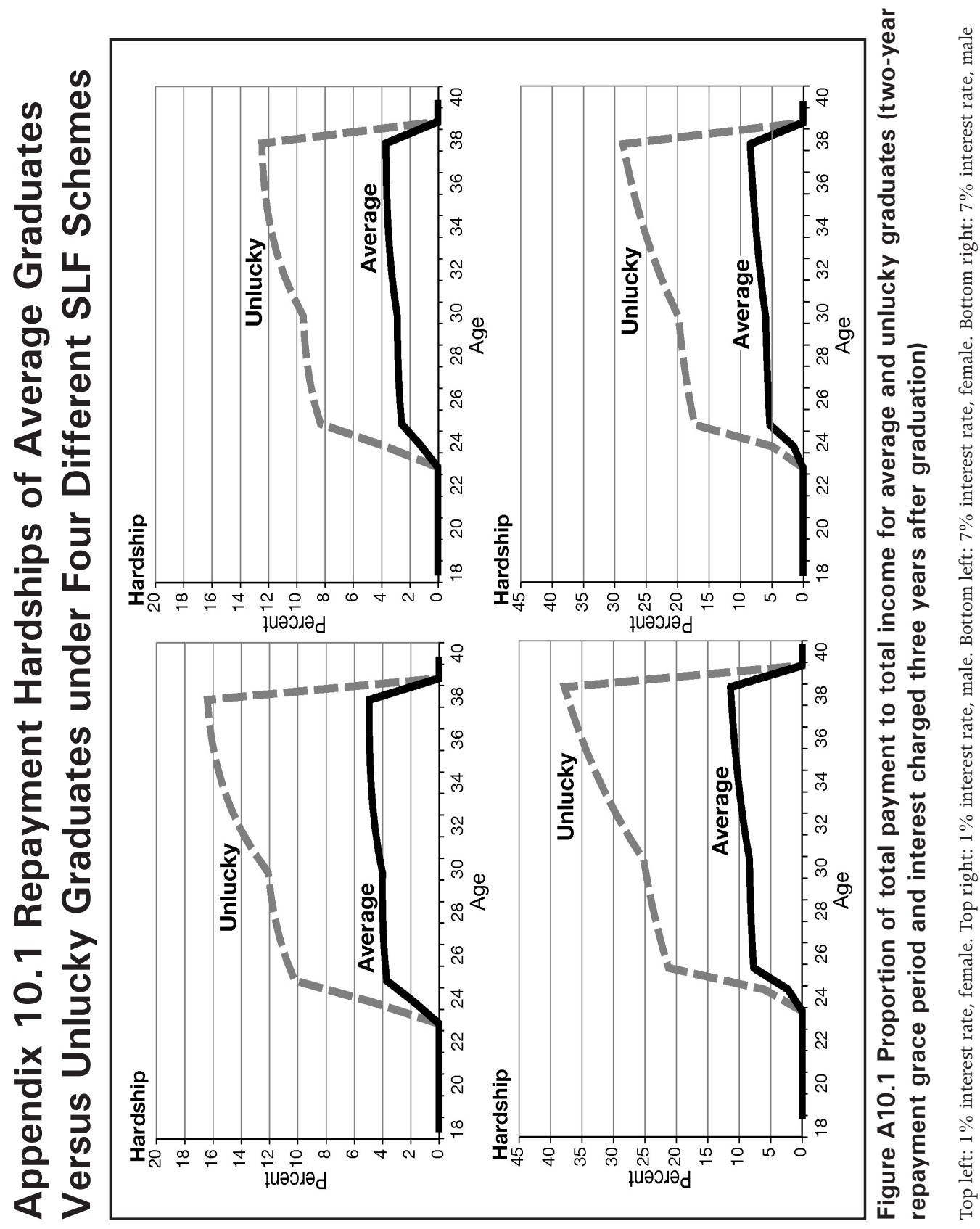




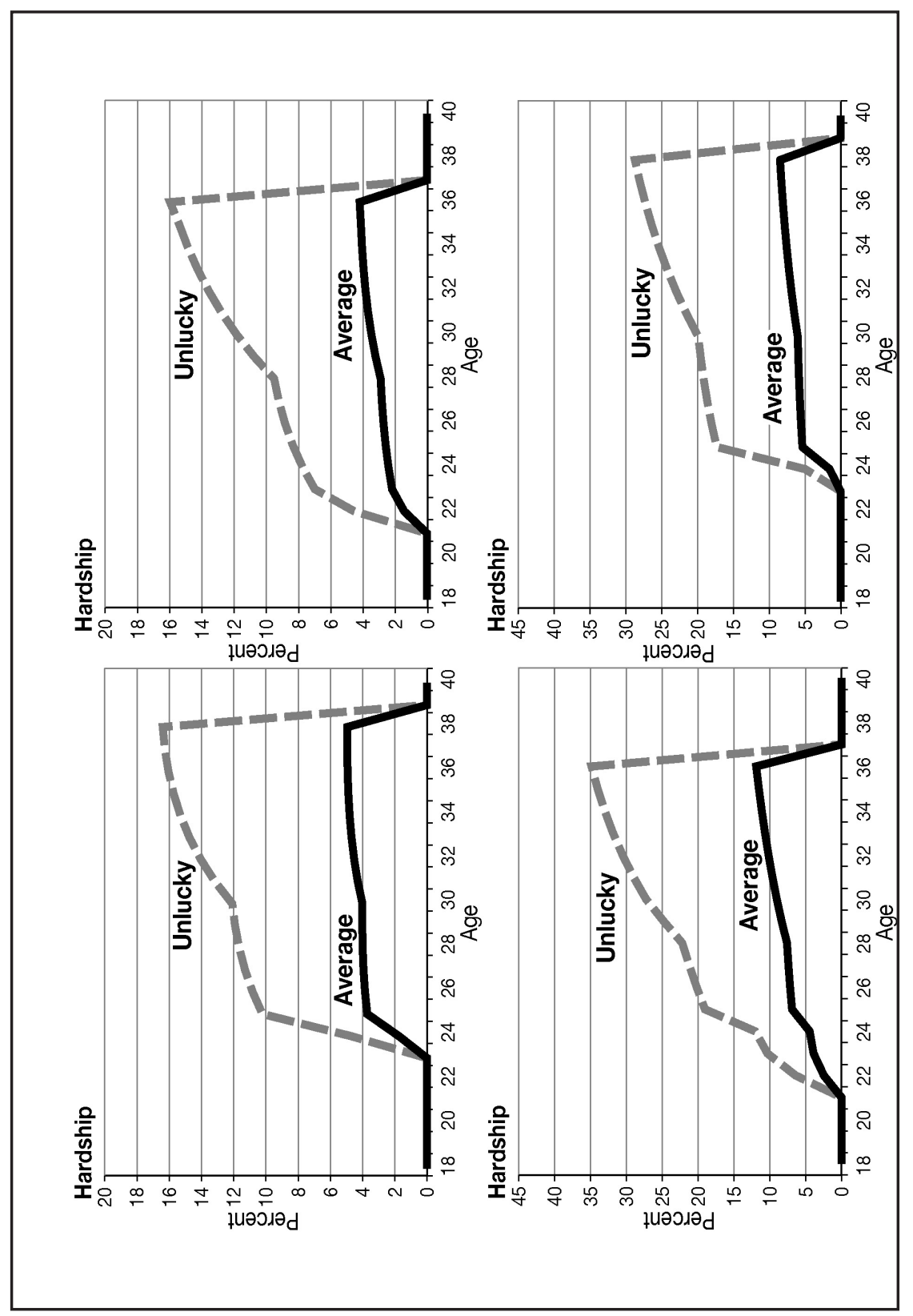

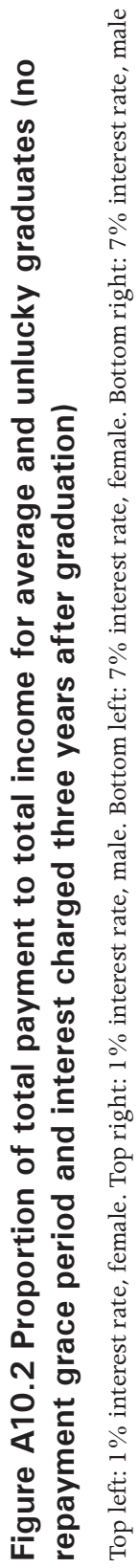


10. Thailand's Student Loans Fund

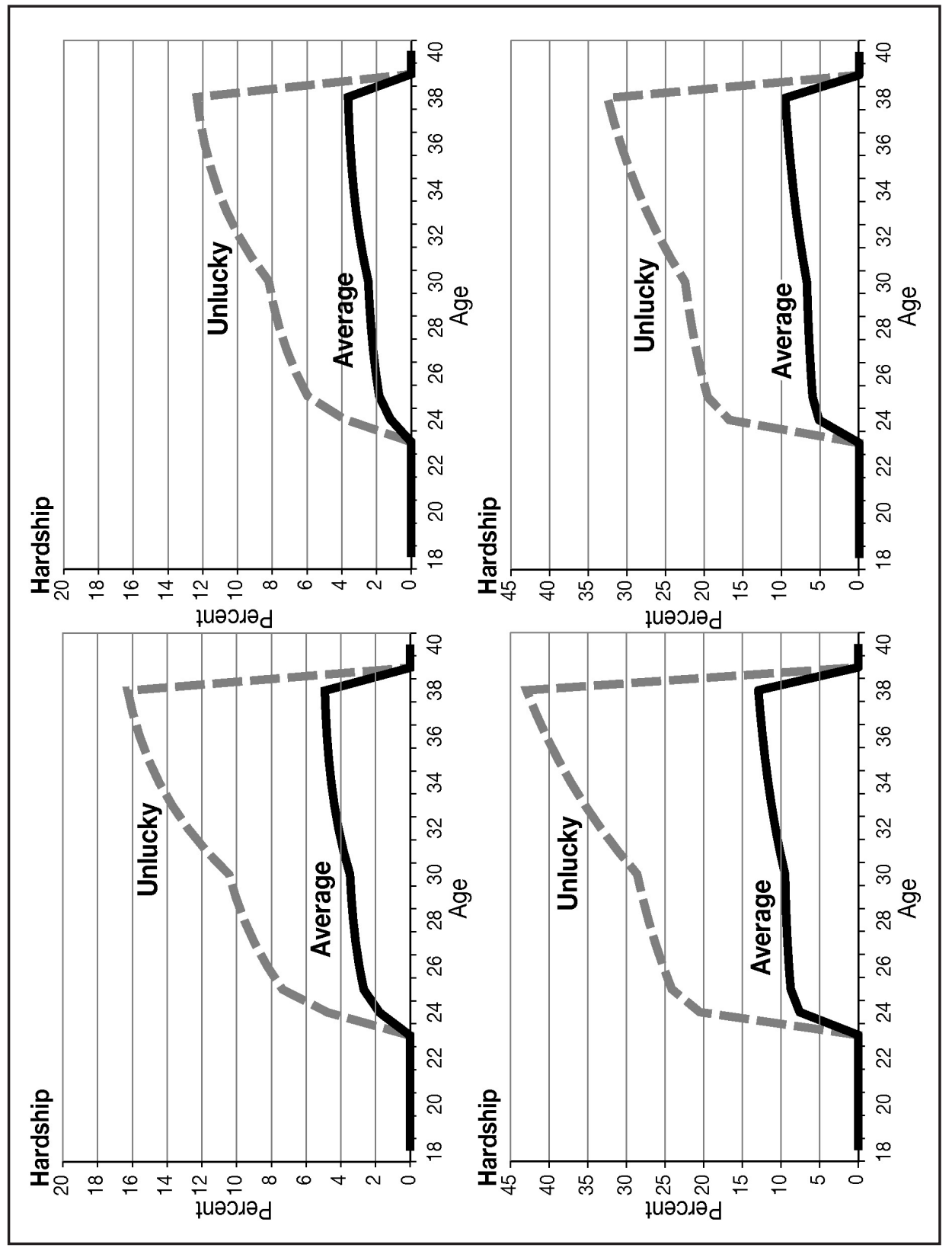

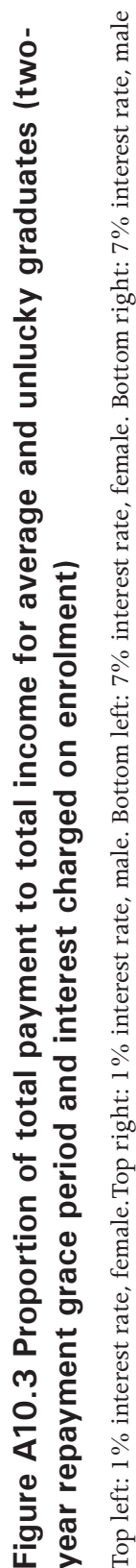




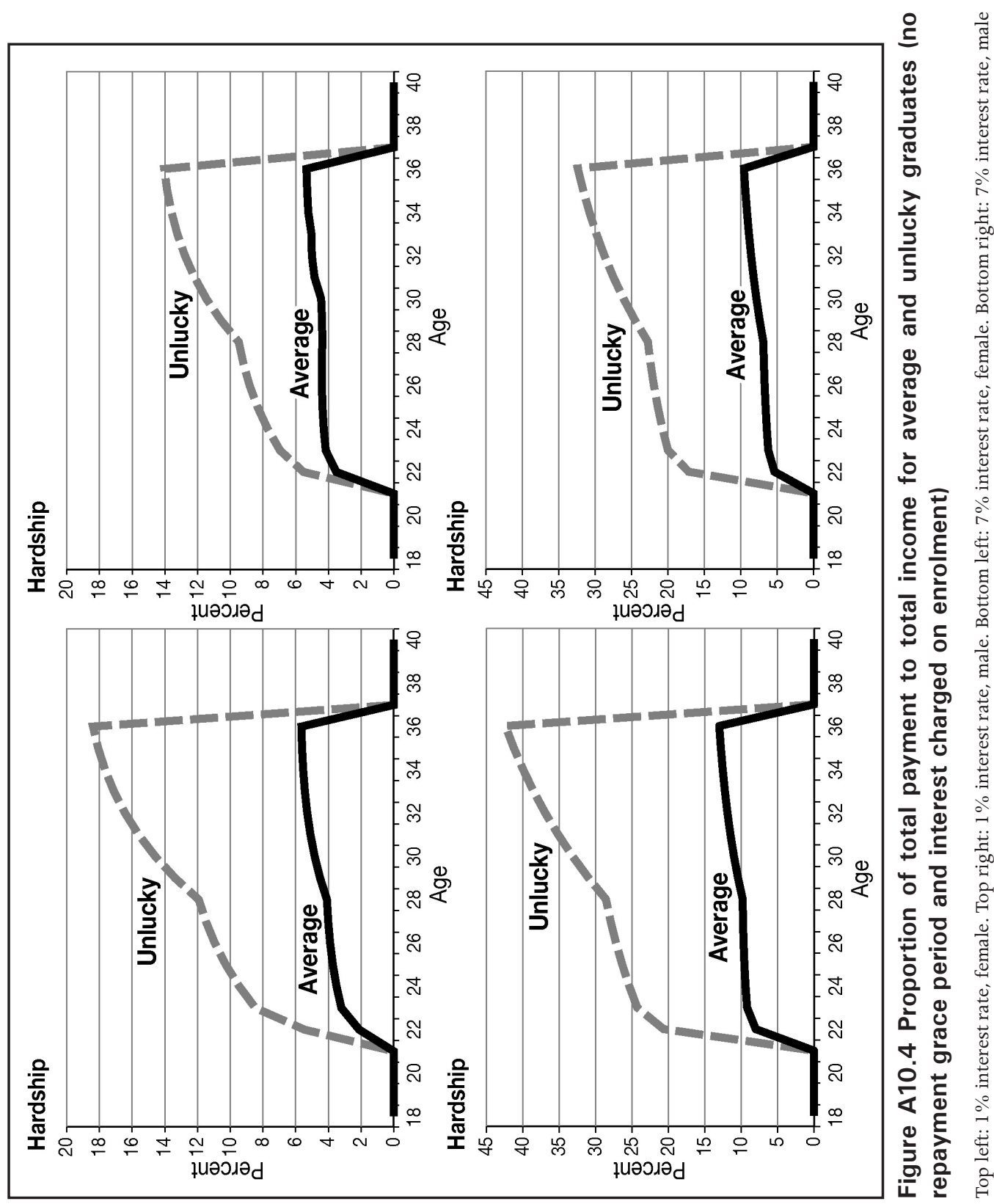

